\title{
'SAK UWONGSAKUWIT' FOR ENVIRONMENTAL PROTECTION BASED ON LOCAL WISDOM: AN ENVIRONMENTAL LAW REFORM IN INDONESIA
}

\author{
Ridwanto Ardi Kusumo ${ }_{\varpi}$,Anang Wahyu Kurnianto ${ }^{2}$ \\ ${ }^{1}$ Notary and Official Certifier of Title Deeds, Kendal Regency, Indonesia \\ ${ }^{2}$ Cakra Justice Law Office, Batang, Indonesia \\ $\triangle$ ridwantoardi@gmail.com
}

\section{CITED AS}

Kusumo, R.A., \& Kurninato, A.W. (2020). 'Sak Uwong Sak Uwit' for Environmental Protection Based on Local Wisdom: An Environmental Law Reform in Indonesia. Journal of Law and Legal Reform, 1(1), 35-48. DOI: https://doi.org/10.15294/jllr.vlil.35451

\section{ABSTRACT}

The research is examines the local wisdom values of Sak Uwong Sak Uwit as environmental protection in the context of local regulation. After the issuance of the regulation, of course it must be understood how the implementation of the regulation and how to supervise the implementation of this policy in Pegandon Village, Pegandon District, Kendal Regency. This research is a sociological juridical research with a qualitative approach, with research locations in Kendal District Community and Village Empowerment Agency and Pegandon Village. The technique of checking the validity of the data uses source triangulation and technique triangulation techniques. Analysis of the data used is an interactive analysis model. This study concluded that, first, in Pegandon Village running the program of Sak Uwong Sak Uwit (SUSU) was only at the beginning of the year, because of its lack of approval by the people who had to bear the burden of costs, non-existent planting land and management of unclear results. Then, the second shows that the lack of seriousness of the Regional Government in terms of guidance and supervision of this program has an impact on the Implementation of the Sak Uwong Sak Uwit (SUSU) Local Regulation.

Keywords: Local Wisdom; Regional Regulations; Implementation; Environmental Protection 


\section{TABLE OF CONTENTS}

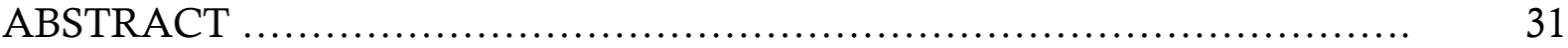

TABLE OF CONTENTS ..................................................... 32

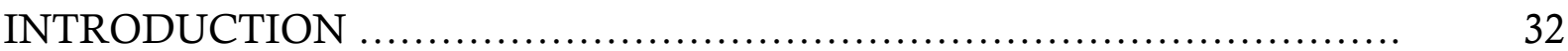

I. THEORETICAL BASIS ..................................................... 35

A. Theory of the Law System of Perspective Lawrence M. Friedman ........ $\quad 35$

B. Monitoring Theory …................................................. 35

C. Theory of Coaching ................................................... 36

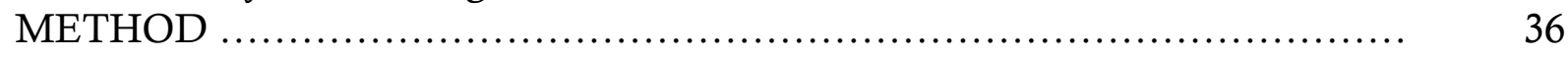

SAK UWONG SAK UWIT AND ENVIRONMENTAL LAW REFORM ...

I. ENVIRONMENTAL PROTECTION BASED ON LOCAL WISDOM IN THE IMPLEMENTATION OF SAK UWONG SAK UWIT BASED ON REGIONAL REGULATION NUMBER 3 OF 2012 IN KENDAL

REGENCY ..........................................................

II. MONITORING OF THE IMPLEMENTATION OF SAK UWONG SAK UWIT (SUSU) BASED ON REGIONAL REGULATION NUMBER 3 OF 2012 CONCERNING PLANTING TREES FOR PROSPECTIVE BRIDE AND CHILD GIVING BIRTH IN KENDAL REGENCY .................. CONCLUSION ........................................................... 40

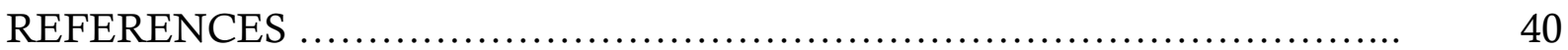

\section{INTRODUCTION}

The Environment is the Creation of God Almighty who had existed in the world for several years before humans existed. Human relations with the environment are interrelated and both are interdependent, we can imagine if humans live without the environment (Yang, Hu, Du, Geng, \& Shi, 2019). The existence of an environment that grows around humans can help humans in managing the air (O2) that is inhaled by it.

In Indonesia, various ways have been sought by the government, including by improving legal instruments especially those related to the Environment (Agbele, Ojeme, \& Jiang, 2019). One legal product approved by the government is Law Number 32 Year 2009 concerning Environmental Protection and Management. The law, which took effect in October 2009 and is listed in the Republic of Indonesia State Gazette Number 140 of 2009, replaces the role of Law Number 23 of 1997 concerning Environmental Management. Law Number 32 of 2009 is believed to have a more comprehensive level of comprehensiveness and discussion when compared to Law Number 23 of 1997.

Local wisdom is a cultural identity or personality. These identities and personalities naturally adjust to the viewpoints of the surrounding community so that values are not shifted, meaning that local wisdom is one of the means in cultivating culture and defending themselves from unfamiliar foreign cultures (Avriel-Avni, Avni, 
Babad, \& Meroz, 2019). In addition, it can be interpreted as a way of life and knowledge as well as a variety of life strategies in the form of activities carried out by local communities in answering various problems in meeting their needs. Broadly speaking, this local wisdom arises from ideas that arise and develop continuously in a society in the form of customs and daily habits (Delebarre, Chiaverini, Vandersteen, \& Savoldelli, 2019).

Awareness of the importance of maintaining environmental balance is not a new thing for us. Long before the regulation, our ancestors had the wisdom to preserve the environment in their own way in accordance with the way of thinking and traditions that took place in his day, has been able to create ways and media to preserve environmental balance natural. Environmental management is now the government's business and responsibility (Asiyanbi, Ogar, \& Akintoye, 2019). Through regional autonomy in accordance with Law No. 23 of 2014 concerning the implementation of regional autonomy, local governments are given power and authority from the central government to regulate and manage their own regions (Akgün, 2020). Specifically in relation to regional autonomy, regional autonomy provides a great possibility for better environmental management. Thus the region can make policies that are environmentally sound (Adu-Gyamfi, 2020).

As one of the regencies in Central Java Province, Kendal Regency has quite good regional characteristics and is promising to be developed in various development sectors. This is because Kendal Regency is one of the regencies located in the main route of the North Coast of Java or better known as the Pantura area (Kumar, Gaur, Zhan, \& Luo, 2018). The location of Kendal Regency, which borders directly with Semarang City as the Capital of Central Java Province, has more or less had an influence on the development of Kendal Regency. There are a lot of potentials in Kendal Regency which are basically still managed irregularly. In fact it was revealed that in managing the potential of the community not yet thinking of business or commercial, but rather emphasizing the adequacy of meeting family needs (Kons, Steinbach, \& Kivestu, 2016). The technology used is simple technology. Such conditions can be related to the relatively low level of community education and the tendency of the nature of the villagers to accept the conditions as they are (Forester, 2019). The problem of human resources and manpower that is less than optimal in the development and empowerment of human resources in Kendal Regency is the background of this writing to see one of the efforts of the Kendal Regency government in empowering and improving the economy of the community, especially rural communities through Regional Regulation Number 3 of 2012 concerning Planting Trees for Grooms and Gives Birth, which later became better known as the Regional Regulations of Sak Uwong Sak Uwit (SUSU).

Tree planting by the bride and groom to give birth is expected to not only function as a greening facility but also provide educational and economic value to the community. So that the program is expected to open many business opportunities and employment in villages in Kendal Regency (Immink, Sperna Weiland, van den Dool, van der Ster, \& Hollmann, 2019). This Regional Regulations was born as a form of Kendal District government concern, towards the environment and Kendal community as a means of environmental education and community economy, as well 
as a form of community empowerment in Kendal Regency. In Article 2 of this regional regulation explained that, this Regional Regulation is intended to reduce global warming caused by carbon dioxide gas emissions and the greenhouse effect, and to empower rural communities to drive rural economic efforts (Elangovan \& Suddaby, 2019).

For this reason, this regulation is expected to be able to achieve the objectives referred to in Article 3, namely to:

a. Greening in the Regions;

Greening in the area here is reforestation in Kendal Regency through trees planted by the community. The regulation explains that every bride and groom giving birth must plant hard-stemmed fruit trees; produce fruit; has economic value; and function as a shelter on land owned by Pre-brides or on open space provided by the local village government, except for people who cannot afford it (Iwamoto \& Ueyama, 2018).

b. Empower Regional communities;

The Regional Regulation previously explained also aims to empower and improve the economy of the Kendal community. Form of empowerment here is divided into two, namely: (l) community empowerment in the environmental field; and (2) community empowerment in the economic field.

Community empowerment in the field of environment is to provide education to the Kendal community about the importance of protecting the environment, especially trees (Kaffine, 2019). Through trees there are many benefits that can be obtained by the community such as shade, fresh and clean air, and even improve the economy if managed properly. Through this regional regulation, it is hoped that Kendal people will be more concerned with the existence of trees and the wider environment, so that Kendal Regency will be created in a way of cooperation. Then the second form of empowerment is the economic empowerment of the Kendal community, especially rural communities in Kendal Regency (Efferth, $\mathrm{Xu}$, \& Lee, 2019). The obligation to plant fruit trees for the bride and groom to give birth is intended so that fruit trees that have been planted can produce fruits of economic value that can help the economy of the grower community itself. So that it can drive new economic activities and open new jobs.

c. Creating new jobs; and

In accordance with the implementation of this regional regulation in a real and consistent manner it is expected to create new jobs in Kendal. For example, by implementing a tree planting policy, the need for tree seedlings increases, tree seed entrepreneurs themselves need various materials such as fertilizers, polybags and so on to produce tree seedlings that are ready for sale (Peleg, Bodas, Shenhar, \& Adini, 2018). This is where new jobs are created which will absorb the existing workforce in Kendal District, so that unemployment and lack of employment in Kendal can be overcome. The real expected outcome is the creation of new entrepreneurs in Kendal Regency and automatically creates a variety of choices and types of new jobs (Pretorius, Mathews, Maré, Kleingeld, \&e van Rensburg, 2019).

d. Driving regional economic ventures.

The latest implementation of this Regional Regulation aims to improve the economy of the Kendal community, and to move the existing economic businesses 
better. The bride and groom giving birth who planted in the village Bondo or ex village Bondo and already have a Tree Planting Certificate (Sertifikat Tanam Pohon, hereinafter as STP), in this regulation explained that they are entitled to take the results of the fruit tree. The results of the fruit trees can be accommodated in advance by village cooperatives formed by the village government. Besides that, Pre-Brides and her mother who already have STP, are also members of the cooperative (Mayor, 2019).

The wisdom and knowledge systems and ideal models of traditional technologies that still need to be explored and studied, because many of them have positive implications for environmentally sound development programs (Nguyen, Truong, Rockwood, \& Tran Le, 2019). Knowing their perceptions about the environment will provide input for efforts to preserve, preserve and improve the quality of the environment in rural areas while remaining grounded in the community's legal awareness of the traditional wisdom that they have had for generations (Doormann, Reyes-garc1, \& Martin-lopez, 2019).

The formulation of the problems in this study are (1) How Environmental Protection Based on Local Wisdom in the Implementation of Sak Uwong Sak Uwit Based on Regional Regulation Number 3 of 2012 in Kendal Regency. (2) How to supervise the implementation of Sak Uwong Sak Uwit (SUSU) Based on Local Regulation No. 3 of 2012 concerning Tree Planting for PreBrides and Mothers giving birth in Kendal Regency.

\section{THEORETICAL BASIS}

\section{A. Theory of the Law System of Perspective Lawrence M. Friedman}

The theory about the elements of the legal system put forward by Friedman (2013: 12) is well known for the elements of the legal system (three elements law system). According to him, in a country that implements a legal system, there must be at least three elements that will be used as the basis or foundation for the country's legal system to be strong. The three elements are: legal structure (legal structure), legal substance (legal substance), legal culture (legal culture). The legal structure is the entire existing legal institutions and their apparatuses, including the police and police officers, prosecutors with prosecutors, courts and judges, and others (Friedman. Terj khozim, 2009: 204). In short according to the author, the structure is law enforcement agencies, such as the mayor and his apparatus / SKPD.

\section{B. Monitoring Theory}

Monitoring is one function in management to ensure that the implementation of work runs according to standards set in the plan. Siagian in Syafi'i (2008) said that monitoring is the process of observing the implementation of all organizational activities to ensure that all work carried out in accordance with a predetermined plan. Saragih (2010) states that supervision is the activity of managers who strive for work to be carried out in accordance with predetermined plans and or desired results. While Reksohadiprodjo (2011) states that supervision is an effort to give instructions 
to the implementers so that they always act according to plan. Another opinion regarding supervision is stated by Hasibuan (2011) which states that supervision is the activity of a leader who strives for work to be carried out according to plan.

In the Indonesian dictionary (KBBI) the term "Oversight comes from the word alert which means to pay close attention, in the sense of looking at things accurate and exact, there are no more activities except to give reports based on the actual reality of what is being watched" (Sujamto, 1986).

In general, the organization of public organizations is needed to ensure that the implementation of government activities runs in accordance with the plan and in accordance with applicable laws and regulations. Implementation of supervision at Government Agencies will require the existence of the Chairperson or Head of Field as a subject in conducting supervisory activities to his subordinates (Moreda, 2018).

Based on these experts, it can be concluded that supervision is the leadership activities of each organization that makes sure that the work is carried out in accordance with the plans set or the desired results by supervising the work carried out by subordinates (Mahapatra et al., 2019).

\section{Theory of Coaching}

According to Widjaja coaching is a process or development that includes sequences of understanding, beginning with establishing, needing, maintaining that growth accompanied by efforts to improve, perfect, and develop (Wong, Campos-Baniak, \& Sharma, 2019).

According to Janus Sidabalok in his book Legal Protection in Indonesia coaching implies assistance, guidance, and assistance for businesses and the consumer community so that he can survive and always grow towards a better direction through the achievement of good performance. In that condition, the business actor can fulfill his obligations well (Janus, 2006).

With the establishment of the implementation of the Sak Uwong Sak Uwit (SUSU) Regional Regulation, it can increase public understanding and awareness, both attitude awareness and responsibility in every activity required by the local government so that it will minimize the effectiveness of this regulation (Lehrer, Juhl, $\& \&$ Gschwend, 2019). The task of coaching is in accordance with Regional Regulation No. 3 of 2012 carried out by the Regent or related technical office.

\section{METHOD}

The method used in this study is a qualitative research method. Qualitative research is research that intends to understand the phenomena about what is experienced by research subjects. This research is a research procedure that produces descriptive data, such as what is stated by respondents in writing or verbally and real behavior. What is researched and studied is a whole object of research, as long as it concerns humans. Thus, then by using a qualitative approach, a researcher primarily aims to understand or comprehend the symptoms being examined (Soekanto, 2012; Arifin, 
Waspiah \& Latifiani, 2018)). Research with this method serves to more easily understand phenomena that occur in society that are not yet widely known so that the phenomena in this research can have a positive impact on governments, academics, students and the community. Researchers in this case, want to see clearly on how effective Regional Regulation No. 3 of 2012 on Planting Trees for PreBrides and Mothers giving birth in their implementation has been implemented or not in Pegandon Village, Pegandon District, Kendal Regency.

This research will be carried out maximally with a view to obtaining complete and truthful data (Soekanto, 2005). Therefore, the type of research the writer will use is juridical-sociological. The workings of this sociological or empirical method are the results of the collection and discovery of data and information through a literature study of the basic assumptions or assumptions used in answering problems in thesis research. Number 3 of 2012 concerning Planting Trees for PreBrides and Mothers. The type of data used in this study are primary and secondary data (Wan, Williamson, \& Pandit, 2019; Arifin, Waspiah \& Latifiani, 2018). This research activity certainly requires a place of research that will serve as a background to obtain the data needed to support the achievement of research objectives (Wiwanitkit, 2019). Determination of the place of research is related to the existence of data or information in accordance with the objectives of the study. This research is planned to be carried out at the Community and Village Empowerment Office, Religious Affairs Office Pegandon District, Pegandon Village Hall, and the residence of Pegandoni Village Community Leaders, Pegandon District Kendal Regency.

Techniques and data collection in this study were interviews, observation. Checking the validity of the data is done by triangulation techniques, there are several types of triangulation techniques namely sources, methods, researchers and theories (Yang et al., 2019). Triangulation with "source" means comparing and checking back the confidence of information obtained through different time and tools. This can be achieved by: comparing observational data with interview data; comparing what others say in public with what is said in private; comparing one's perspective and perspective with various opinions and views of people such as ordinary people, people with secondary and higher education, people who are and people in government; comparing the results of the interview with a related document (Amirudin and Zainal Asikin: 2006, 98). The author compares theories with interview results. In conclusion, because the most widely used triangulation technique is examination through other sources, the authors only use triangulation with sources.

This study processes data in four stages, namely data collection, data reduction, data presentation and conclusions. The four components affect and are interrelated(Weng, Hsu, \& Liu, 2019). First, researchers conduct research in the field using interviews called the data collection stage. Because the data collected is a lot then a data reduction is held, after being reduced then a data presentation is held, in addition to that the data collection is also used for data presentation. When both stages are completed, a conclusion is drawn (Wei, 2019). The data collected in this research is obtained through research conducted through interviews and documents (Ramirez, Ravetz, Sharpe, \& Varley, 2019). These data pertain to the focus of the research, namely Environmental Protection Based on Local Wisdom in the 
Implementation of Sak Uwong Sak Uwit Based on Regional Regulation Number 3 of 2012 in Kendal Regency.

\section{SAK UWONG SAK UWIT AND ENVIRONMENTAL LAW REFORM}

\section{ENVIRONMENTAL PROTECTION BASED ON LOCAL WISDOM IN THE IMPLEMENTATION OF SAK UWONG SAK UWIT BASED ON REGIONAL REGULATION NUMBER 3 OF 2012 IN KENDAL REGENCY}

According to the results of research in Pegandon village, Pegandon sub-district, Kendal Regency, researchers found data regarding the implementation of the Sak Uwong Sak Uwit (SUSU) regional policy which was intended for brides and grooms. According to data from a study conducted in Pegandon village Pegandon District Kendal Regency researchers observed the opinion of the Head of Field II Village Social Culture Empowerment and the Development of Community and Village Empowerment Institutions and Community and Village Empowerment Agency, Head of religious Affairs office Pegandon District, village head, village apparatus, and figures the community, regarding the Regional Regulations Sak Uwong Sak Uwit (SUSU), which concerns tree planting for brides and grooms giving birth when applied in Pegandon village, has factors that influence its implementation in the Pegandon village.

The implementation of Sak Uwong Sak Uwit (SUSU) based on Regional Regulation Number 3 of 2012 concerning Planting Trees for Pre-Bride and Child Giving Birth has been implemented at the beginning of this regulation. With the passage of time and the change of Regional Head, this Regulation is no longer implemented. Regional Regulation Number 3 of 2012 concerning Planting Trees for PreBrides and Gives Birth in Kendal District, Pegandon Village Communities in general already know the program commonly referred to as this SUSU Regional Regulation. Pegandon Village Community Pegandon District Kendal Regency does not agree with regional regulations on tree planting for brides and grooms giving birth for various reasons including the added cost of buying trees, limited land and lost tree yields during harvest time. In addition, the lack of regular socialization from the Government, hampered the course of this program because the community did not know very well how to implement tree planting and there was no legal certainty which was realized in the form of binding sanctions. Besides that, there are no bureaucratic structure (SOP (standard operation procedure) that governs the implementation procedures.

According to Friedman, he argues about legal culture, legal culture concerns legal culture, which is a human attitude (including the legal culture of law enforcement officials). Simply put, as well as structuring the legal structure to carry 
out the established legal rules and made without the support of legal culture by the people involved in the system and society, law enforcement will not run optimally or effectively. Law as a tool to change society or social engineering is nothing but ideas that the law wants to realize. To guarantee the achievement of the legal function as a better engineered society, not only is the availability of law in terms of rules or regulations needed, but also guarantees for the realization of the rule of law, or in other words, a guarantee for law enforcement. good (Munir Fuady, 2003: 40).

In general, the Pegandon Village community does not agree with the Regional Regulations Sak Uwong Sak Uwit (SUSU) which is intended for brides and grooms giving birth due to various factors that have been summarized through the results of the above research.

\section{MONITORING OF THE IMPLEMENTATION OF SAKUWONG SAKUWIT (SUSU) BASED ON REGIONAL REGULATION NUMBER 3 OF 2012 CONCERNING PLANTING TREES FOR PROSPECTIVE BRIDE AND CHILD GIVING BIRTH IN KENDAL REGENCY}

The Kendal Regency Community and Village Empowerment Service (Dispermasdes) is a government agency that is authorized and responsible for carrying out the process of fostering and controlling conditions related to the Sak Uwong Sak Uwit Regional Regulation (SUSU), in accordance with Article 12 of Local Regulation No. 3 of 2012 concerning Planting Trees for Grooms and Gives Birth.

The Kendal Regency Community and Village Empowerment Agency (Dispermasdes) has HR support consisting of:

Number of Structural Position Human Resources (HR):
1. Agency Head (Es. II / b)
$: 1$ person
2. Head of Division (Es. III.b)
: 4 people
3. Head of Subdivisions (Es. IV.a)
: 3 people
4. Head of Sub Division (Es. IV.a)
: 8 people

Total Human Resources (HR) by rank:
1. Junior Administrator (IV / c)
: 1 person
2. First Class Administrator (IV / b)
$: 1$ person
3. Administrator (IV/a)
:7 people
4. First Class Superintendent (III / d)
: 7 people
5. Superintendent (III / c)
:7 people
6. First Class Junior Superintendent (III / b)
: 10 people
7. Junior Superintendent (III / a)
: 2 people
8. First Class Supervisor (II / b)
: 2 people
9. Supervisor (II / c)
: 2 people 
10. First Class Junior Supervisor (II / b)

11. Junior Supervisor (II / a)

12. Non-permanent employees (PTT)
: 4 people

$: 1$ person

$: 1$ person

Total Human Resources (HR) by Education Level:
1. Postgraduate (S2)
2. Bachelor (S1)
: 5 people
3. Expert (D4)
: 21 people
4. Associate Expert (D3)
: 0 people
5. Senior High School
6. Junior High School
7. Elementary School
Total Amount
: 5 people
: 14 people
:0 people
$: 0$ people
: 45 people

Kendal Dispermasdes played a role in coordinating government programs by conducting socialization in each District of Kendal Regency. In accordance with what was stated by Mr. Amin Fatoni, S.E., M.T Head of Division II:

"Institutionally DISPERMASDES oversees full socialization until the implementation of activities. For our own socialization, we have done it in every district by presenting community leaders, RELIGIOUS AFFAIRS OFFICE employees and village parties "(Interview 31 October 2012).

Based on the results of observations in the field, researchers found several phenomena that showed that the implementation of supervision and coaching had not been carried out optimally. This is shown from the statements of the components of the village community and related institutions that the authors studied, namely in Pegandon village, Pegandon district, Kendal regency.

Regional Regulation Number 3 of 2012 precisely in Article 12 which mentions guidance and supervision cannot be carried out optimally, due to the lack of clarity in the bureaucratic structure in this program and the absence of SOP (Standard Operational Procedure). The lack of supervision of the implementation of tree planting for brides and grooms gives birth to the community easily ignores the obligations that should be carried out according to existing regulations.

According to Siagian in the Supervision theory the book quote from ir. Sujamto titled Some Understanding in the field of Supervision, the government should carry out a process of observing the implementation of all activities carried out by the Office of Community Empowerment and the Village of Kendal Regency, this is to ensure that all work is carried out in accordance with the previously agreed provisions.

According to the Guiding theory that Mangunhardjono said, the Government must also carry out an informative, participatory and experimental approach. So that all of the Local Government programs run effectively and efficiently. 


\section{CONCLUSION}

Based on the results of research and discussion, the researcher can conclude as follows: The Implementation of Sak Uwong Sak Uwit (SUSU) based on Regional Regulation Number 3 of 2012 concerning Planting Trees for Prospective Brides and Gives Birth has been implemented at the beginning of this regulation. With the passage of time and the change of Regional Head, this Regulation is no longer implemented. Regional Regulation Number 3 of 2012 concerning Planting Trees for Prospective Brides and Gives Birth in Kendal District, Pegandon Village Communities in general already know the program commonly referred to as this SUSU Regional Regulations. Pegandon Village Community Pegandon District Kendal Regency does not agree with regional regulations on tree planting for brides and grooms giving birth for various reasons including the added cost of buying trees, limited land and lost tree yields during harvest time. In addition, the lack of regular socialization from the Government hampered the course of this program because the community did not know very well how to implement tree planting and there was no legal certainty which was realized in the form of binding sanctions.

Oversight is carried out by the Kendal District Community and Village Empowerment Office even though it is stated in Article 12 of Regulation No. 3 of 2012 concerning Planting Trees for Prospective Brides and Gives Birth but this has not been realized properly. Rules that state guidance and supervision cannot be implemented because of the lack of clarity in the bureaucratic structure in this program and the absence of SOP (Standard Operational Procedure). The lack of supervision of the implementation of tree planting for brides and grooms gives birth to the community easily ignores the obligations that should be carried out according to existing regulations.

\section{REFERENCES}

Adu-Gyamfi, A. (2020). Connecting religion to homeownership: exploring local perspectives in Ghana. Cities, 96 (January 2019), 102441. https://doi.org/10.1016/j.cities.2019.102441

Agbele, T., Ojeme, B., \& Jiang, R. (2019). Application of local binary patterns and cascade AdaBoost classifier for mice behavioural patterns detection and analysis. Procedia Computer Science, 159, 1375-1386. https://doi.org/10.1016/j.procs.2019.09.308

Akgün, A. E. (2020). Team wisdom in software development projects and its impact on project performance. International Journal of Information Management, 50(May 2019), 228-243. https://doi.org/10.1016/j.ijinfomgt.2019.05.019

Arifin, R., Waspiah, W., \& Latifiani, D. (2018). Penulisan Karya Ilmiah untuk Mahasiswa Hukum. Semarang: BPFH UNNES.

Asiyanbi, A. P., Ogar, E., \& Akintoye, O. A. (2019). Complexities and surprises in local resistance to neoliberal conservation: Multiple environmentalities, technologies of the self and the poststructural geography of local engagement with REDD+. 
$\begin{array}{lll}\text { Political Geography, } & \text { 69(May } & \text { 2018), }\end{array}$ https://doi.org/10.1016/j.polgeo.2018.12.008

Avriel-Avni, N., Avni, Y., Babad, A., \& Meroz, A. (2019). Wisdom dwells in places: What can modern farmers learn from ancient agricultural systems in the desert of the Southern Levant? Journal of Arid Environments, 163(December 2017), 86-98. https://doi.org/10.1016/j.jaridenv.2018.11.009

Delebarre, H., Chiaverini, C., Vandersteen, C., \& Savoldelli, C. (2019). Orofacial management for epidermolysis bullosa during wisdom tooth removal surgery: A technical note. Journal of Stomatology, Oral and Maxillofacial Surgery, (2018), 4-7. https://doi.org/10.1016/j.jormas.2019.03.007

Doormann, L., Reyes-garc1, V., \& Martin-lopez, B. (2019). Learning from Indigenous Populations and Local Communities. One Earth, 1(1), 16-17. https://doi.org/10.1016/j.oneear.2019.07.002

Efferth, T., Xu, A.-L., \& Lee, D. Y. W. (2019). Combining the wisdoms of traditional medicine with cutting-edge science and technology at the forefront of medical $\begin{array}{lll}\text { sciences. } & \text { Phytomedicine, } & \text { 64(July), }\end{array}$ https://doi.org/10.1016/j.phymed.2019.153078

Elangovan, A. R., \& Suddaby, R. (2019). Solomons for our times: Wisdom in decisionmaking in organizations. Organizational Dynamics. https://doi.org/10.1016/j.orgdyn.2019.03.001

Forester, J. (2019). Ecological wisdom through deliberative improvisation: Theory and practice in challenging cases. Journal of Urban Management, 8(1), 12-19. https://doi.org/10.1016/j.jum.2018.04.003

Friedman, L.M. (2018). Sistem Hukum Perspektif Ilmu Sosial. Bandung: Nusa Media.

Immink, R. V., Sperna Weiland, N. H., van den Dool, R. E. C., van der Ster, B. J. P., \& Hollmann, M. W. (2019). Cerebral autoregulation: with age comes wisdom. British Journal of Anaesthesia, 123(3), e466-e468. https://doi.org/10.1016/j.bja.2019.06.006

Iwamoto, M., \& Ueyama, D. (2018). Basis of self-organized proportion regulation resulting from local contacts. Journal of Theoretical Biology, 440, 112-120. https://doi.org/10.1016/j.jtbi.2017.12.028

Kaffine, D. T. (2019). Microclimate effects of wind farms on local crop yields. Journal of Environmental Economics and Management, 96, 159-173. https://doi.org/10.1016/j.jeem.2019.06.001

Kons, M., Steinbach, K., \& Kivestu, T. (2016). Local Cultural Heritage Usage in Music Studies in South-eastern Estonian Schools. Procedia-Social and Behavioral Sciences, 217, 531-536. https://doi.org/10.1016/j.sbspro.2016.02.036

Kumar, V., Gaur, A., Zhan, W., \& Luo, Y. (2018). Co-evolution of MNCs and local competitors in emerging markets. International Business Review, (xxxx). https://doi.org/10.1016/j.ibusrev.2018.08.002

Lehrer, R., Juhl, S., \& Gschwend, T. (2019). The wisdom of crowds design for sensitive $\begin{array}{llll}\text { survey questions. } & \text { Electoral } & \text { Studies, } & 57,\end{array}$ https://doi.org/10.1016/j.electstud.2018.09.012

Mahapatra, A. Das, Bhowmik, P., Banerjee, A., Das, A., Ojha, D., \& Chattopadhyay, D. 
(2019). Ethnomedicinal Wisdom. In New Look to Phytomedicine. https://doi.org/10.1016/b978-0-12-814619-4.00003-3

Mayor, R. (2019). Collective Cell Migration: Wisdom of the Crowds Transforms a Negative Cue into a Positive One. Current Biology, 29(6), R205-R207. https://doi.org/10.1016/j.cub.2019.02.001

Moreda, T. (2018). Contesting conventional wisdom on the links between land tenure security and land degradation: Evidence from Ethiopia. Land Use Policy, 77(April), 75-83. https://doi.org/10.1016/j.landusepol.2018.04.058

Nguyen, A. T., Truong, N. S. H., Rockwood, D., \& Tran Le, A. D. (2019). Studies on sustainable features of vernacular architecture in different regions across the world: A comprehensive synthesis and evaluation. Frontiers of Architectural Research, (xxxx). https://doi.org/10.1016/j.foar.2019.07.006

Peleg, K., Bodas, M., Shenhar, G., \& Adini, B. (2018). Wisdom of (using) the crowds: Enhancing disasters preparedness through public training in Light Search and Rescue. International Journal of Disaster Risk Reduction, 31(July), 750-757. https://doi.org/10.1016/j.ijdrr.2018.07.027

Pretorius, J. G., Mathews, M. J., Maré, P., Kleingeld, M., \& van Rensburg, J. (2019). Implementing a DIKW model on a deep mine cooling system. International Journal of Mining Science and Technology, 29(2), 319-326. https://doi.org/10.1016/j.ijmst.2018.07.004

Ramirez, R., Ravetz, J., Sharpe, B., \& Varley, L. (2019). We need to talk (more wisely) about wisdom: A set of conversations about wisdom, science, and futures. Futures, 108, 72-80. https://doi.org/10.1016/j.futures.2019.02.002

Reksohadiprodjo. (2011). Organisasi dan Manajemen Sumber Daya Manusia. Jakarta: Bumi Aksara.

Republic of Indonesia. (2004). Law Number 32 of 2004 concerning Regional Government (Undang-Undang Nomor 32 Tahun 2004 Tentang Pemerintahan Daerah).

Republic of Indonesia. (2012). Regional Regulation Number 3 of 2012 concerning Planting Trees for Prospective Brides and Gives Birth (Peraturan Daerah Nomor 3 Tahun 2012 Tentang Penanaman Pohon Bagi Calon Pengantin dan Ibu Melahirkan).

Saragih. (2010). Manajemen Kinerja. Jakarta: Raja Grafindo.

Siagian, S. (2011). Manajemen Sumber Daya Manusia. Jakarta: Bumi Aksara.

Soekanto, S. (1986). Pengantar Penelitian Hukum. Jakarta: Universitas Indonesia.

Sujamto. (1986). Beberapa Pengertian di Bidang Pengawasan. Jakarta: Ghalia Indonesia.

Syafi'i. (2008). Ilmu Administrasi Negara. Jakarta: Gunung Agung.

Wan, F., Williamson, P., \& Pandit, N. R. (2019). MNE liability of foreignness versus local firm-specific advantages: The case of the Chinese management software industry. International Business Review, (January), 101623. https://doi.org/10.1016/j.ibusrev.2019.101623

Wei, B. (2019). Commentary: Going the distance: The effect of margin length on local recurrence after wedge resection for colorectal metastases. Journal of Thoracic and Cardiovascular Surgery, 157(4), 1656-1657. https://doi.org/10.1016/j.jtcvs.2018.11.015

Weng, Y., Hsu, K. C., \& Liu, B. J. (2019). Increasing worldwide environmental 
consciousness and environmental policy adjustment. Quarterly Review of Economics and Finance, 71, 205-210. https://doi.org/10.1016/j.qref.2018.08.003

Wiwanitkit, V. (2019). Alcoholic Beverage Production in Indochina: Local Wisdom, Safety, Quality, and Legal Control. In Production and Management of Beverages. https://doi.org/10.1016/b978-0-12-815260-7.00013-4

Wong, M., Campos-Baniak, M. G., \& Sharma, V. (2019). Occipital lobe abscess following wisdom tooth extraction. Canadian Journal of Ophthalmology, 54(3), el45el49. https://doi.org/10.1016/j.jcjo.2018.08.001

Yang, R., Hu, K., Du, C., Geng, Y., \& Shi, L. (2019). Coveting neighbors' wisdom promotes cooperation in structured populations. Chaos, Solitons and Fractals, 122, 202-205. https://doi.org/10.1016/j.chaos.2019.03.023 